\title{
Analisis sub sektor industri pengolahan unggulan di Provinsi Kepulauan Bangka Belitung
}

\author{
Hamzah* \\ Fakultas Ekonomi, Universitas Bangka Belitung, Indonesia
}

\begin{abstract}
Abstrak Penelitian ini bertujuan untuk mengidentifikasi jenis-jenis industri yang menjadi industri pengolahan unggulan di Provinsi Kepulauan Bangka Belitung. Alat analisis yang digunakan adalah analisis Location Quotient dan Analisis Shift Share. Hasil penelitian dari analisi $L Q$ menunjukkan bahwa industri yang menjadi industri unggulan di Provinsi Kepulauan Bangka Belitung antara lain yaitu industri makanan dan minuman, industri karet, barang dari karet dan plastik, industri bahan galian bukan logam, serta industi logam. Sedangkan sub sektor industri pengolahan yang tidak unggul yaitu Industri Tekstil dan Pakaian Jadi, Industri Kayu, Barang dari Kayu, dan Gabus dan Barang Anyaman dari Bambu, Rotan, dan sejenisnya, Industri Kertas dan Barang dari Kertas, Percetakan dan Reproduksi Media Rekaman, Industri Barang Logam, Komputer, Barang Elektronik, Optik; dan Peralatan Listrik, Industri Furnitur, serta Industri Pengolahan Lainnya (Jasa Reparasi, dan Pemasangan Mesin, dan Peralatan). Penggabungan analisis LQ dan Shift Share menunjukkan hasil bahwa sub sektor industri pengolahan unggulan terdapat pada Industri Karet, Barang dari Karet, dan Plastik, karena memiliki 2 keunggulan sekaligus yaitu keunggulan komparatif dan keunggulan kompetitif.
\end{abstract}

Kata kunci: industri unggulan; location quotient; shift share; keunggulan komparatif; keunggulan kompetitif

\begin{abstract}
The purpose of this study is to identify the types of industries that are leading industries in the Bangka Belitung Islands Province. The analytical tool used is Location Quotient analysis and Shift Share Analysis. The results of the LQ analysis show that industries that are leading industries in the Bangka Belitung Islands Province include the food and beverage industry, the rubber industry, rubber and plastic goods, the non-metal mining industry, and the metal industry. While the manufacturing industry sub-sectors that are not superior are the Textile and Apparel Industry, the Timber Industry, Wood Products, and Cork and Woven Goods from Bamboo, Rattan, and the like, the Paper Industry and Paper Products, Printing and Reproduction of Recording Media, the Goods Industry Metals, Computers, Electronics, Optics; and Electrical Equipment, Furniture Industry, and Other Processing Industries (Repair Services, and Machine, and Equipment Installation). The merger of LQ analysis and Shift Share shows the results that the leading manufacturing sub-sector is found in the Rubber Industry, Rubber Products, and Plastics, because it has two advantages at once namely comparative advantage and competitive advantage
\end{abstract}

Keywords: leading industry; location quotient; shift share; comparative advantage; competitive advantage

JEL Classification: C1O; E66; L16 


\section{PENDAHULUAN}

Sektor industri pengolahan merupakan salah satu dari sektor-sektor ekonomi yang memiliki komponen penting dalam upaya meningkatkan penerimaan negara, yaitu Pendapatan Domestik Bruto (PDB) nasional yang telah menggeser peran sektor pertanian yang semula merupakan sektor primer dalam pembangunan (Sari, 2014). Barthwal (2010) menyatakan pendapatnya bahwa industri adalah suatu organisasi yang dimiliki oleh seseorang atau beberapa orang secara bersama-sama yang terlibat dalam berbagai bentuk aktivitas ekonomi produktif. Shodiqin (2018) juga menyatakan pendapatnya bahwa industri adalah kumpulan perusahaan yang menghasilkan barang yang sejenis yang mempunyai nilai tambah. Sedangkan menurut Julianto dan Suparno (2016), industri adalah sekumpulan usaha-usaha yang sejenis dalam menghasilkan produksi barang maupun jasa. Pengertian industri ini dapat disimpulkan bahwa industri adalah sekelompok perusahaan yang menjalankan kegiatan usaha dalam meningkatkan nilai tambah pada suatu barang atau jasa. Sektor industri basis/unggulan merupakan suatu kegiatan ekonomi yang menjadi penunjang perekonomian yang telah dapat melebihi kebutuhan dari suatu daerah, sehingga telah dapat diekspor ke daerah lainnya. Waloyo (2018) menyatakan bahwa kegiatan basis adalah semua kegiatan yang menghasilkan output nilai tambah baik dari penghasil produk maupun penyedia jasa yang mendatangkan keuntungan dari luar wilayah. Sedangkan, kegiatan non basis adalah sektor ekonomi yang memenuhi kebutuhan konsumsi lokal, karena permintaan sektor non basis sangat dipengaruhi oleh tingkat perubahan pendapatan masyarakat setempat. Menurut Santoso (2017), keberadaan sektor basis adalah hal yang paling penting untuk diketahui, karena pada pembangunan suatu daerah yang mengandalkan potensi sumber daya akan dapat berjalan dengan baik jika sektor basis daerah dapat dioptimalkan.

Kebijakan ekonomi sektoral yang paling strategis adalah kebijakan ekonomi yang berfokus pada sektor industri. Namun, tidak semua industri mampu bertahan pada kegiatan dunia usaha. Hasibuan (1994) menegaskan bahwa industri akan tetap bertahan apabila suatu industri mampu mengambil keputusan dengan tepat dalam mengakses input sehingga mampu melakukan produksi secara maksimal dengan biaya yang minimal, industri mampu mengidentifikasikan kebutuhankebutuhan konsumen sesuai perkembangan zaman, industri mampu memberikan intensif terbaik kepada para pemangku kebijakan, serta industri mampu menciptakan iklim organisasi yang baik sehingga dapat membuat strategi yang baik pula dalam persaingan usaha. Irmawati (2015) mengatakan sektor industri dipandang sebagai sektor yang memiliki tingkat produktivitas tinggi, sehingga keunggulannya akan memperoleh nilai tambah yang tinggi pula. Tujuan dalam menciptakan kesejahteraan ekonomi masyarakat akan lebih cepat terwujud dengan mengembangkan sektor tersebut. Namun, tidak semua daerah memiliki potensi pada sektor tersebut. Pengembangan ekonomi daerah harus tetap didasarkan pada potensi yang dimiliki oleh masing-masing daerah, hal ini dilakukan supaya tujuan dasar mendorong kemajuan daerah yaitu terciptanya kesejahteraan masyarakat dapat segera tercapai. 
Provinsi Kepulauan Bangka Belitung merupakan daerah yang memiliki potensi sumber daya alam yang sangat besar. Salah satu sumber daya yang paling besar di Provinsi Kepulauan Bangka Belitung adalah bergerak pada sektor industri pengolahan. Industri pengolahan di Provinsi Kepulauan Bangka Belitung memiliki kontribusi terbesar terhadap pertumbuhan ekonomi dalam penunjang perekonomian. Artinya, industri pengolahan memiliki peran yang penting bagi perekonomian Kepulauan Bangka Belitung. Oleh Karena itu, tujuan pembangunan akan segera tercapai apabila pemerintah dapat memfokuskan kebijakannya untuk mendorong pertumbuhan industri pengolahan yang basis. Hal ini dikarenakan, pertumbuhan pada sektor basis akan berdampak pula terhadap pertumbuhan sektor lainnya yaitu sektor non basis. Hal ini sejalan dengan penelitian Jayanti dan Moqorobin (2017) menyatakan pendapatnya bahwa peningkatan daya saing pada sektor industri pengolahan merupakan salah satu penghasil ekspor haruslah diupayakan perkembangannya, dengan cara menjadikan sektor industri pengolahan menjadi prioritas perdagangan pada pasar internasional.

ertumbuhan sektor industri pengolahan di Provinsi Kepulauan Bangka Belitung menunjukkan peningkatan yang konsisten setiap tahunnya. Selama 5 tahun terakhir, PDRB sektor industri pengolahan di Provinsi Kepulauan Bangka Belitung semakin meningkat setiap tahunnya. Pada Gambar 1 disajikan grafik dari PDRB sektor Industri Pengolahan di Provinsi Kepulauan Bangka Belitung.

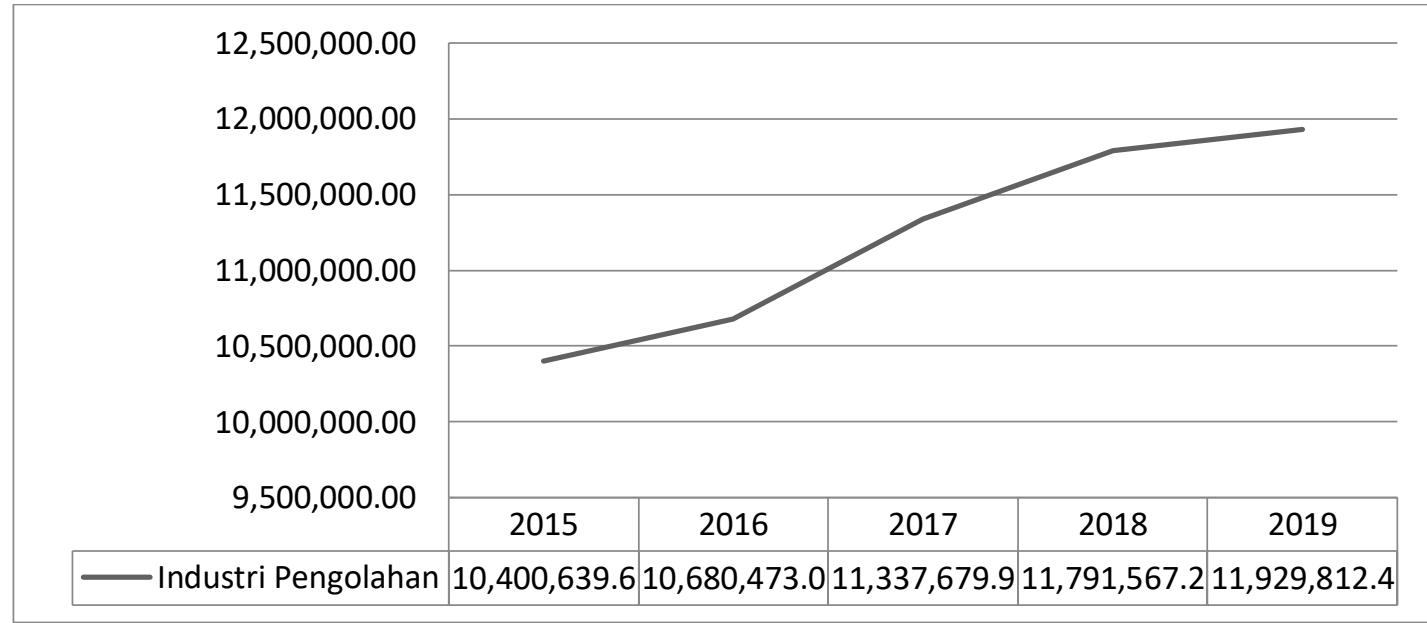

Sumber: Badan Pusat Statistik Provinsi Kepulauan Bangka Belitung (2020), diolah peneliti

Gambar 1. PDRB Sektor Industri Pengolahan

Gambar 1 menunjukkan bahwa PDRB sektor industri pengolahan di Provinsi Kepulauan Bangka Belitung selama periode 2015-2019 mengalami peningkatan setiap tahunnya. PDRB sektor industri pengolahan telah mengalami pertumbuhan pada periode tahun 2019 sebesar 14,70 persen terhadap periode tahun 2014 . Walaupun mengalami pertumbuhan yang melambat setiap tahunnya, tetapi PDRB sektor pengolahan menunjukkan peningkatan yang konsisten setiap tahunnya. Artinya, industri pengolahan di Provinsi Kepulauan Bangka Belitung memiliki potensi yang sangat besar. Dengan demikian, apabila potensi tersebut dikembangkan dengan optimal maka secara tidak langsung akan memiliki benefit untuk daerah dalam menunjang perekonomian. Hal ini sejalan dengan pendapat Santoso (2017) 
bahwa suatu daerah akan dapat mencapai peningkatan pembangunan ekonomi apabila daerah tersebut mengembangkan potensi sektor unggulan secara optimal.

Penelitian ini didasarkan dari beberapa penelitian terdahulu yang digunakan sebagai acuan dalam penulisan. Penelitian yang dilakukan oleh Irmawati (2015) menggunakan metode analisis Location Quotient (LQ), SLQ dan DLQ, dan shift share. Hasil penelitian menunjukkan bahwa industri yang menjadi industri unggulan di Provinsi Jawa Tengah antara lain industri minuman, industri pengolahan tembakau, industri tekstil, industri pakaian jadi, industri kayu, industri percetakan, industri furnitur, serta industri pengolahan lainnya.

Wahyuningsih (2015) dalam penelitiannya menggunakan metode analisis Indeks Daya Penyebaran (IDP), Indeks Derajat Kepekaan (IDK), dan Revealed Comparative Advantage (RCA). Hasil penelitian menyatakan bahwa terdapat 9 industri unggulan di Jawa Tengah yaitu industri pengolahan dan pengawetan ikan, industri minyak dan lemak, industri penggilingan padi, industri tepung terigu dan tepung lainnya, industri makanan ternak, industri pemintalan, industri tekstil, industri kayu dan bahan bangunan dari kayu, serta industri karet dan barang dari karet. 9 industri unggulan tersebut yang memiliki daya saing ekspor tinggi hanya ada 3 industri yaitu industri pemintalan, industri tekstil, dan industri kayu dan bahan bangunan dari kayu.

Mangilaleng et al., (2015) juga melakukan penelitian dengan metode analisis LQ dan shift share. Hasil penelitian menunjukkan bahwa sektor unggulan di Kabupaten Minahasa Selatan yaitu sektor pertambangan, sektor pertanian sektor konstruksi, sektor industri, dan sektor yang mempunyai daya saing terbesar di Kabupaten Minahasa Selatan yaitu: sektor pertanian, sektor konstruksi, sektor industri.

Penelitian Arif dan Utomo (2016) metode analisis shift share, Location Quotient dan menggunakan analisis Sistem Informasi Geografis (SIG). Penelitian menemukan hasil bahwa dalam skala regional Kota Surakarta memiliki lima industri unggulan yaitu makanan dan minuman, tekstil dan produk tekstil/aneka, pakaian jadi, percetakan, dan industri mebel/furnitur. Produk unggulan di Kota Surakarta memiliki konsentrasi sangat tinggi berada di 4 Kecamatan yaitu Kecamatan Jebres, Kecamatan Laweyan, Kecamatan Serengan, dan Kecamatan Pasar Kliwon.

Pradigda (2016) pada penelitiannya menggunakan metode analisis shift share, Analytical Hierarchy Process, dan SWOT. Penelitian ini menemukan hasil bahwa Berdasarkan hasil analisis shift share dan AHP, ditemukan kerajinan tempurung kelapa sebagai produk unggulan di Kabupaten Blitar. Selanjutnya penyusunan strategi dalam hal pengembangan produk tersebut menggunakan analisis SWOT.

Fasyah et al., (2016) juga melakukan penelitian menggunakan analisis Analytical Hierarchy Proses (AHP) dan Metode Perbandingan Eksponensial (MPE). Hasil penelitian menemukan bahwa produk yang berpotensi menjadi produk unggulan UMKM sektor industri agro di Kabupaten Bogor, yaitu minuman sari pala. Implikasi penelitian ini yaitu menetapkan minuman sari pala sebagai produk unggulan daerah Kabupaten Bogor, Pemerintah daerah perlu menjaga ketersediaan 
pasar dengan melakukan pemasaran intensif dan pengembangan kerja-sama dengan mitra, serta melakukan peningkatan produksi dan mutu perkebunan sebagai upaya menjaga ketersediaan dan meningkatkan efisiensi pengadaan bahan baku, peningkatan keterampilan tenaga kerja dengan pengadaan pelatihan secara menyeluruh kepada masyarakat.

Penelitian Kharisma dan Hadiyanto (2018) menggunakan metode analisis LQ, Growth Ratio Model (MRP), dan Overlay analysis. Hasil penelitian menemukan bahwa Provinsi Maluku terdapat 8 kategori ekonomi yang memiliki sektor basis, yaitu kategori pertanian, kehutanan dan perikanan; kategori pengadaan air, pengelolaan sampah dan daur ulang; kategori perdagangan besar-eceran dan reparasi mobil-sepeda motor; kategori transportasi dan pergudangan; kategori administrasi pemerintahan, pertahanan dan jaminan sosial wajib; kategori jasa pendidikan; kategori jasa kesehatan dan kegiatan sosial; dan kategori jasa lainnya. Model Rasio Pertumbuhan (MRP) menunjukkan bahwa sektor yang memiliki nilai rata-rata Pertumbuhan Regional (RPs) tertinggi di Provinsi Maluku yakni sektor Pertambangan dan Penggalian. Selanjutnya, analisis overlay menunjukkan bahwa sektor administrasi pemerintahan, pertahanan, jaminan sosial wajib dan perdagangan besar dan eceran; reparasi mobil dan sepeda motor merupakan kegiatan yang sangat dominan baik dari pertumbuhan maupun dari kontribusi yang sangat besar terhadap pembentukan PDRB dan pembangunan di Provinsi Maluku.

Berdasarkan latar belakang yang telah diuraikan, maka penelitian ini bertujuan untuk mengetahui sub sektor industri pengolahan unggulan di Provinsi Kepulauan Bangka Belitung serta pergeseran dan perubahan sub sektor industri pengolahan di Provinsi Kepulauan Bangka Belitung tahun 2015-2019.

\section{METODE}

Penelitian ini menggunakan pendekatan penelitian deskriptif kuantitatif yaitu penelitian empiris yang sifatnya menjelaskan data-data yang diperoleh dengan hasil analisis yang dilakukan sehingga memberikan penjelasan berupa fenomenafenomena yang menjadi permasalahan penelitian (Sugiyono, 2014).

Penelitian ini dilakukan di wilayah Provinsi Kepulauan Bangka Belitung. Wilayah Provinsi Kepulauan Bangka Belitung menjadi pilihan pada penelitian ini dikarenakan, wilayah ini tergolong wilayah kepulauan dengan potensi sumber daya yang sangat besar dan cocok untuk pembanguanan industri pengolahan. Waktu penelitian dalam proses analisis data yang digunakan berada pada periode tahunan yaitu tahun $2015-2019$.

Jenis data yang digunakan adalah data kuantitatif periode tahun 2015-2019. Data kuantitatif adalah suatu proses dalam melakukan atau menemukan pengetahuan dan fakta menggunakan data berupa angka sebagai alat menganalisis keterangan mengenai apa yang ingin diketahui (Sugiyono, 2014). Sumber data pada penelitian ini yaitu bersumber dari data sekunder yang diperoleh dari lembaga yang relevan dengan penelitian ini. Data sekunder adalah data yang diperoleh peneliti dari sumber yang telah ada. Data sekunder tersebut berupa data PDRB sub 
sektor industri pengolahan di Provinsi Kepulauan Bangka Belitung dan Data PDB sub sektor industri pengolahan di Indonesia yang diperoleh dari Statistik Dasar Badan Pusat Statistik (2020).

Metode analisis yang Digunakan pada penelitian ini adalah Location Quotient dan analisis Shift Share. Location Quotien adalah analisis yang membandingkan besaran peran sektor ekonomi di daerah tertentu atas peranan sektor serupa di kepemerintahan yang lebih tinggi (Tarigan, 2005). Analisis LQ juga digunakan untuk menentukan sektor basis dan non basis dengan karakteristik $L Q>1$ maka sektor tersebut memiliki spesialisasi, $L Q<1$ tidak memiliki spesialisasi, sedangkan $L Q=1$ memiliki spesialisasi sama dengan sektor serupa dikepemerintahan diatasnya. Berikut rumus perhitungan dari analisis LQ:

Keterangan:

$$
L Q=\frac{Y i j / Y j}{Y i w / Y w}
$$

LQ : nilai LQ

Yij : nilai output jenis industri (i) Provinsi Kepulauan Bangka Belitung

Yj : nilai total output industri Provinsi Kepulauan Bangka Belitung

Yiw : nilai output jenis industri (i) Indonesia

Yw : nilai total output industri Indonesia

Analisis Shift Share merupakan alat analisis yang dapat digunakan untuk mengetahui sektor-sektor ekonomi manakah yang termasuk dalam sektor yang memiliki keunggulan kompetitif atau mampu bersaing dengan sektor yang sama didaerah lain dan sektor-sektor yang tidak memiliki keunggulan kompetitif dengan melihat nilai $\mathrm{Cij}$ pada hasil perhitungannya. Sektor dikatakan memiliki keunggulan kompetitif jika sektor tersebut mampu bersaing dengan sektor yang sama di daerah lain. Nilai Cij dapat diukur dengan menggunakan rumus:

$$
C i j=Y i j(r i j-r i w)
$$

Dengan:

$$
\begin{aligned}
r i j & =\left\{\frac{\left(Y i j-Y^{*} i j\right)}{Y^{*} i j}\right\} \times 100 \\
r i w & =\left\{\frac{\left(Y i w-Y^{*} i w\right)}{Y^{*} i w}\right\} \times 100
\end{aligned}
$$

Keterangan:

Cij : nilai komponen keunggulan kompetitif

Yij : nilai output industri (i) Provinsi Kepulauan Bangka Belitung tahun 2019

$Y^{*}$ ij $\quad$ : nilai output industri (i) Provinsi Kepulauan Bangka Belitung tahun 2015

Yiw : nilai output industri (i) Indonesia tahun 2019

$\mathrm{Y}^{*}$ iw : nilai output industri (i) Indonesia tahun 2015 
rij : laju pertumbuhan industri (i) Provinsi Kepulauan Bangka Belitung dari tahun 2015-2019

riw : laju pertumbuhan industri (i) Indonesia dari tahun 2015-2019

Ketentuan penilaian keunggulan komparatif melalui Shift Share yaitu apabila nilai Cij menunjukkan angka yang positif maka komoditas tersebut memiliki keunggulan kompetitif. Sedangkan jika nilai Cij menunjukkan angka yang negatif maka komoditas tersebut tidak memiliki keunggulan kompetitif.

\section{HASIL DAN PEMBAHASAN}

\section{Analisis Location Quotien (LQ)}

Analisis Location Quotien akan menghasilkan penentuan sub sektor industri unggulan yang ada di Provinsi Kepulauan Bangka Belitung. Sub Sektor Industri dikatakan unggul apabila memiliki nilai $L Q>1$, sedangakan nilai $L Q<1$ merupakan sub sektor industri pengolahan yang tidak memiliki keunggulan. Tabel 1 menampilkanhasil perhitungan analisis LQ di Provinsi Kepulauan Bangka Belitung:.

Tabel 1. Hasil Analisis LQ Sub Sektor Industri Pengolahan di Provinsi Kepulauan Bangka Belitung

\begin{tabular}{|c|c|c|c|c|c|c|}
\hline Sub Sektor Industri Pengolahan & 2015 & 2016 & 2017 & 2018 & 2019 & $\begin{array}{c}\text { Rata- } \\
\text { rata }\end{array}$ \\
\hline $\begin{array}{l}\text { Industri Batubara dan Pengilangan } \\
\text { Migas }\end{array}$ & - & - & - & - & - & 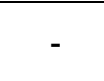 \\
\hline Industri Makanan dan Minuman & 1,01 & 1,00 & 1.00 & 1,00 & 1,00 & 1,00 \\
\hline Industri Pengolahan Tembakau & - & - & - & - & - & - \\
\hline Industri Tekstil dan Pakaian Jadi & 0,05 & 0,05 & 0,05 & 0,05 & 0,05 & 0,05 \\
\hline $\begin{array}{l}\text { Industri Kulit, Barang dari Kulit dan } \\
\text { Alas Kaki }\end{array}$ & - & - & - & - & - & - \\
\hline $\begin{array}{l}\text { Industri Kayu, Barang dari Kayu dan } \\
\text { Gabus dan Barang Anyaman dari } \\
\text { Bambu, Rotan dan Sejenisnya } \\
\text { Industri Kertas dan Barang dari }\end{array}$ & 0,66 & 0,64 & 0,64 & 0,64 & 0,72 & 0,66 \\
\hline $\begin{array}{l}\text { Kertas; Percetakan dan Reproduksi } \\
\text { Media Rekaman }\end{array}$ & 0,10 & 0,10 & 0,11 & 0,13 & 0,14 & 0,12 \\
\hline $\begin{array}{l}\text { Industri Kimia, Farmasi dan Obat } \\
\text { Tradisional }\end{array}$ & 0,03 & 0,03 & 0,03 & 0,03 & 0,03 & 0,03 \\
\hline $\begin{array}{l}\text { Industri Karet, Barang dari Karet dan } \\
\text { Plastik }\end{array}$ & 1.00 & 1.00 & 1,01 & 1.00 & 1.00 & 1,00 \\
\hline Industri Barang Galian bukan Logam & 1,55 & 1,46 & 1,39 & 1,47 & 1,53 & 1,48 \\
\hline $\begin{array}{l}\text { Industri Logam Dasar } \\
\text { Industri Barang Logam; Komputer, }\end{array}$ & 14,74 & 15,16 & 15,15 & 13,89 & 13,75 & 14,54 \\
\hline $\begin{array}{l}\text { Barang Elektronik, Optik; dan } \\
\text { Peralatan Listrik }\end{array}$ & 0,11 & 0,10 & 0,09 & 0,09 & 0,09 & 0,10 \\
\hline Industri Mesin dan Perlengkapan & - & - & - & - & - & - \\
\hline Industri Alat Angkutan & 0,04 & 0,04 & 0,04 & 0,04 & 0,05 & 0,04 \\
\hline $\begin{array}{l}\text { Industri Furnitur } \\
\text { Industri Pengolahan Lainnya; Jasa }\end{array}$ & 0,07 & 0,07 & 0,07 & 0,06 & 0,05 & 0,06 \\
\hline $\begin{array}{l}\text { Reparasi dan Pemasangan Mesin } \\
\text { dan Peralatan }\end{array}$ & 0,23 & 0,24 & 0,25 & 0,25 & 0,26 & 0,25 \\
\hline
\end{tabular}


Tabel 1 menunjukkan sub sektor industri unggulan yang terdapat di Provinsi Kepulauan Bangka Belitung selama periode 2015-2019 yaitu industri makanan dan minuman, industri karet, barang dari karet dan plastik, industri bahan galian bukan logam, serta industri logam. Hal ini menunjukkan bahwa industri-industri yang memiliki nilai $L Q>1$ merupakan industri yang mampu memenuhi permintaan kebutuhan daerah dan mampu mengekspor output yang dihasilkan pada daerah lainnya serta mampu mempengaruhi pertumbuhan ekonomi sektor industri pengolahan di Provinsi Kepulauan Bangka Belitung.

Sub sektor industri pengolahan yang tergolong tidak memiliki keunggulan selama periode 2015-2019 di Provinsi Kepulauan Bangka Belitung yaitu Industri Tekstil Dan Pakaian Jadi, Industri Kayu, Barang dari Kayu, dan Gabus dan Barang Anyaman dari Bambu, Rotan, dan sejenisnya, Industri Kertas dan Barang dari Kertas, Percetakan dan Reproduksi Media Rekaman, Industri Barang Logam, Komputer, Barang Elektronik, Optik; dan Peralatan Listrik, Industri Furnitur, serta Industri Pengolahan Lainnya (Jasa Reparasi, dan Pemasangan Mesin, dan Peralatan). Industri-industri yang memiliki nilai $L Q<1$ menunjukkan bahwa industriindustri tersebut tidak memiliki keunggulan komparatif pada masa sekarang dan masa yang akan datang, karena hanya mampu memenuhi kebutuhan pada daerah saja serta merupakan penunjang sektor basis yang masih harus mengimpor barang dari luar daerah terlebih dahulu untuk terproduksi dalam untuk memenuhi kebutuhan.

\section{Analisis Shift Share}

Suatu industri dapat dikatakan sebagai industri unggulan apabila industri tersebut memiliki dua keunggulan sekaligus yaitu keunggulan komparatif dan keunggulan kompetitif. Suatu industri dikategorikan memiliki keunggulan kompetitif apabila nilai $\mathrm{Cij}$ pada analisis shift share bernilai positif. Sementara apabila nilai Cij pada analisis shift share bernilai negatif maka industri tersebut tidak memiliki keunggulan kompetitif (Irmawati, 2015). Berikut hasil analisis Shift Share sub sektor industri pengolahan di Provinsi Kepulauan Bangka Belitung pada Tabel 2.

Hasil analisis Shift Share pada Tabel 2 menunjukkan kinerja dari masingmasing sub sektor industri pengolahan di Provinsi Kepulauan Bangka Belitung selama periode 2015-2019. Sub sektor industri pengolahan yang memiliki nilai Cij positif yaitu Industri Kayu, Barang dari Kayu, dan Gabus dan Barang Anyaman dari Bambu, Rotan dan sejenisnya, Industri Kertas dan Barang dari Kertas, Percetakan dan Reproduksi Media Rekaman, Industri Karet, Barang dari Karet dan Plastik, Industri Alat Angkutan, Industri Pengolahan Lainnya (Jasa Reparasi dan Jasa Pemasangan Mesin dan Peralatan). Sub Sektor industri Pengolahan yang diklasifikasikan sebagai industri andalan memiliki keunggulan kompetitif karena nilai Cij pada sub sektor industri-industri tersebut bernilai positif. Sehingga, industri tersebut memiliki potensi untuk menjadi industri unggulan pada masa yang akan datang serta mengalami peningkatan daya saing produksi dibandingkan dengan sektor yang sama di Indonesia. Sehingga industri-industri tersebut mampu bersaing dengan industri yang sama dari daerah lain di Indonesia. 
Tabel 2. Hasil Analisis Shift Share Sub Sektor Industri Pengolahan di Provinsi Kepulauan Bangka Belitung

\begin{tabular}{lrc}
\hline Sub Sektor Industri Pengolahan & \multicolumn{1}{c}{ Cij } & Rata-rata LQ \\
\hline Industri Batubara dan Pengilangan Migas & - & - \\
Industri Makanan dan Minuman & $-24.935 .316,7988$ & 1,00 \\
Industri Pengolahan Tembakau & $-92.134,9152$ & - \\
Industri Tekstil dan Pakaian Jadi & - & - \\
Industri Kulit, Barang dari Kulit dan Alas Kaki & & \\
Industri Kayu, Barang dari Kayu dan Gabus dan & $1.459 .647,3834$ & 0,66 \\
Barang Anyaman dari Bambu, Rotan dan & & \\
Sejenisnya & & 0,12 \\
Industri Kertas dan Barang dari Kertas; Percetakan & $2.192 .664,8603$ & 0,03 \\
dan Reproduksi Media Rekaman & $-312.720,5754$ & 1,00 \\
Industri Kimia, Farmasi dan Obat Tradisional & $4.114 .063,8723$ & 1,48 \\
Industri Karet, Barang dari Karet dan Plastik & $-2.300 .044,8373$ & 14,54 \\
Industri Barang Galian bukan Logam & $-71.868 .599,3383$ & 0,10 \\
Industri Logam Dasar & $-1.393 .101,1671$ & - \\
Industri Barang Logam; Komputer, Barang & & - \\
Elektronik, Optik; dan Peralatan Listrik & & - \\
Industri Mesin dan Perlengkapan & $71.594,3430$ & 0,04 \\
Industri Alat Angkutan & $-174.233,1401$ & 0,06 \\
Industri Furnitur & & \\
Industri Pengolahan Lainnya; Jasa Reparasi dan & $217.909,8323$ & 0,25 \\
Pemasangan Mesin dan Peralatan & &
\end{tabular}

Sumber: Badan Pusat Statistik Provinsi Kepulauan Bangka Belitung (2020), diolah peneliti

Sub sektor industri pengolahan yang memiliki nilai $\mathrm{Cij}$ negatif yaitu Industri Makanan dan Minuman, Industri Tekstil dan Pakaian Jadi, Industri Kimia, Farmasi, dan Obat Tradisional, Industri Bahan Galian Bukan Logam, Industri Logam Dasar, Industri Barang Logam, Komputer, Barang Elektronik, Optik dan Peralatan Listrik, serta Industri Furnitur. Sub sektor industri pengolahan yang memiliki nilai Cij negatif diklasifikasikan sebagai industri terbelakang. Produk industri-industri tersebut dimungkinkan memiliki daya saing jika dibandingkan dengan produk dari industri yang sama dari daerah lain di Indonesia. Namun. tidak memiliki keunggulan kompetitif karena nilai Cij pada industri-industri tersebut bernilai negatif. Sehingga, industri tersebut belum mampu ekspor pada masa yang akan datang serta tidak mampu bersaing dengan industri yang sama dari daerah lain. Karena, memiliki penurunan daya saing produksi yang menurun dibandingkan dengan sektor yang sama di tingkat industri pengolahan Indonesia.

Industri Pengolahan unggulan terdapat pada industri Karet, Barang dari Karet dan Plastik karena memiliki 2 keunggulan sekaligus baik keunggulan komparatif maupun keunggulan kompetitif. hal ini menunjukkan bahwa industri karet, barang dari karet dan plastik merupakan industri yang unggul baik pada masa sekarang maupun potensinya untuk masa yang akan datang. Hal ini juga dikarenakan Provinsi Kepulauan Bangka Belitung merupakan daerah pengekspor karet sehingga industri karet, barang dari karet dan plastik memiliki potensi untuk dikembangkan pada masa yang akan datang. Lain halnya dengan industri Logam dasar di Provinsi Kepulauan Bangka Belitung, walaupun memiliki nilai LQ paling tinggi diantara industri lainnya, namun industri logam dasar hanya memiliki keunggulan pada masa sekarang tidak memiliki keunggulan kompetitif pada masa yang akan datang. Hal ini 
dikarenakan, industri logam dasar merupakan industri yang memperoleh bahan baku dari hasil pertambangan, sedangkan pertambangan tergolong sumber daya yang tidak dapat terbarukan yang akan pasti akan habis pada masa yang akan datang.

\section{KESIMPULAN}

Berdasarkan hasil penelitian yang telah dijelaskan, peneliti menemukan bahwa sub sektor industri pengolahan unggulan di Provinsi Kepulauan Bangka Belitung selama periode 2015-2019 terdapat pada industri karet, barang dari karet dan plastik. Industri karet, barang dari karet, dan plastik memenuhi dua keunggulan sekaligus baik keunggulan komparatif maupun keunggulan kompetitif. Hal ini dikarenakan, Kepulauan Bangka Belitung merupakan daerah pengekspor bahan baku karet yang cukup besar. Selain itu, komoditas karet adalah komoditas yang berkelanjutan dibandingkan dengan komoditas pertambangan.

Saran untuk penelitian selanjutnya diharapkan menambahkan analisis strategi pengembangan industri karet, barang dari karet, dan plastik dalam meningkatkan perekonomian pasca tambang. Hal ini dimaksudkan untuk meningkatkan hasil tambah dari produksi karet di Provinsi Kepulauan Bangka Belitung, sehingga industri karet menjadi komoditas unggulan di pasar internasional.

\section{DAFTAR PUSTAKA}

(1) Arif, M., \& Utomo, Y.P. (2016). Konsentrasi Spasial Industri-industri Unggulan Kota Surakarta. The 3rd University Research Colloquium (URECOL) 2016, 35-53. https://publikasiilmiah.ums.ac.id/handle/11617/6710

(2) Badan Pusat Statistik Provinsi Kepulauan Bangka Belitung. (2020). Produk Domestik Regionan Bruto Provinsi Kepulauan Bangka Belitung menurut Lapangan Usaha 20152019.

(3) Badan Pusat Statistik. (2020). Produk Domestik Bruto Indonesia Triwulanan 20152019.

(4) Barthwal, R.R. (2010). Industrial Economics: An introductory textbook (2nd Edition). New Age International Publishers Ltd.

(5) Fasyah, D.N., Daryanto, H.K., \& Suprayitno, G. (2016). Penentuan Produk Unggulan Usaha Mikro Kecil Menengah Sektor Industri Agro di Kabupaten Bogor. MANAJEMEN IKM: Jurnal Manajemen Pengembangan Industri Kecil Menengah, 11(2), 103-110. https://doi.org/10.29244/mikm.11.2.103-110

(6) Hasibuan, N. (1994). Ekonomi Industri. LP3ES.

(7) Irmawati, S. (2015). Analisis Industri Unggulan di Provinsi Jawa Tengah. JEJAK: Journal of Economics and Policy, 8(2), 224-237. https://journal.unnes.ac.id/nju/index.php/jejak/article/view/6172

(8) Jayanti, P.T., \& Muqorobin, M. (2017). Analisis Strategi Dan Program Peningkatan Daya Saing Pada Industri Unggulan Provinsi Jawa Tengah Dalam Menghadapi Masyarakat Ekonomi Asean (MEA). Jurnal Ekonomi \& Studi Pembangunan, 18(1), $52-$ 61. https://doi.org/10.18196/jesp.18.1.3952 
(9) Julianto, FT., \& Suparno. (2016). Analisis Pengaruh Jumlah Industri Besar Dan Upah Minimum Terhadap Pertumbuhan Ekonomi Di Kota Surabaya. JEB17: Jurnal Ekonomi dan Bisnis, 1(02), 229-256. http://jurnal.untagsby.ac.id/index.php/JEB17/article/view/914

(10) Kharisma, B., \& Hadiyanto, F. (2018). Penentuan Potensi Sektor Unggulan Dan Potensial di Provinsi Maluku. Jurnal Ekonomi \& Studi Pembangunan, 19(1), 21-34. https://doi.org/10.18196/jesp.19.1.3938

(11) Mangilaleng, E.J., Rotinsulu, D,. \& Rompas, W. (2015). Analisis Sektor Unggulan Kabupaten Minahasa Selatan. Jurnal Berkala IImiah Efisiensi, 15(04), 193-205. https://ejournal.unsrat.ac.id/index.php/jbie/article/view/9482

(12) Pradigda, E.A. (2016). Strategi Perencanaan Pembangunan Industri Berbasis Produk Unggulan Daerah, Studi pada Dinas Perindustrian dan Perdagangan Kabupaten Blitar. Jurnal Paradigma, 5(3), 121-131. http://ejournals.unmul.ac.id/index.php/JParadigma/article/view/434

(13) Santoso, M.B. (2017). Analisis Sektor Perekonomian Unggulan di Kabupaten Magelang Periode 2010-2014 [Unpublished undergraduate thesis]. Universitas Islam Negeri Sunan Kalijaga.

(14) Sari, N. (2014). Konsentrasi Industri Pengolahan di Propinsi Jawa Tengah. Economics Development Analysis Economics Development Analysis Journal, 3(3). http://journal.unnes.ac.id/sju/index.php/edaj/article/view/1038

(15) Shodiqin, A. (2018). Pengaruh Sektor Industri Pengolahan Terhadap Pertumbuhan Ekonomi Kota Bandar Lampung Periode 2010-2016: Perspektif Ekonomi Islam [Unpublished undergraduate thesis]. Fakultas Ekonomi dan Bisnis Islam, Universitas Islam Negeri Raden Intan.

(16) Sugiyono. (2014). Metode Penelitian Pendidikan Pendekatan Kuantitatif, Kualitatif, dan R\&D. Alfabeta.

(17) Tarigan, R. (2005). Ekonomi Regional: Teori dan Aplikasi. Bumi Aksara.

(18) Wahyuningsih, W.S. (2015). Analisis Daya Saing Ekspor Sektor Unggulan di Jawa Tengah. Economics Development Analysis Journal, 4(3), 332-349. https://journal.unnes.ac.id/sju/index.php/edaj/article/view/14840

(19) Waloyo, A. (2018). Analisis Potensi Ekonomi dan Sektor Unggulan Ekonomi di Kabupaten Grobogan Tahun 2010-2015 [Unpublished undergraduate thesis]. IImu Ekonomi Studi Pembangunan, Fakultas Ekonomi dan Bisnis, Universitas Muhammadiyah Surakarta. 